\title{
STUDY OF MANGROVE FOREST EXISTING CONDITION USING REMOTE SENSING IMAGE IN THE KARAWANG COAST OF 2018
}

\author{
R. Ade Komarudin ${ }^{*}$, Aris Kabul Pranoto ${ }^{2}$, Dian Sutono ${ }^{2}$, Anthon A. Djari² \\ ${ }^{1}$ Karawang Fisheries Agency, Jalan Ir Suratin No.1, Nagasari, Keamatan. Karawang Barat, Kabupaten \\ Karawang, Jawa Barat 41314 \\ ${ }^{2}$ Politeknik Kelautan dan Perikanan Karawang, Jalan Lingkar Tanjungpura, Karangpawitan, Kecamatan \\ Karawang Barat, Kabupaten Karawang, Jawa Barat 41315
}

Received: 26 April 2020; Received in revised form: 14 January 2021; Accepted: 24 January 2021

\begin{abstract}
The northern part of Karawang is a coastal area with mostly mud-sand substrates. This substrate tends to be unstable, so that naturally, this kind of sediment is supported by coastal vegetation that forms coastal ecosystems, such as mangroves; therefore, the importance of mangroves in Karawang coast is definite. Unfotunately the data regarding the condition of mangroves in Karawang Regency is quite insufficient. This information, especially about its existence, is needed as a database for further research and as basis to support government policies on coastal area management. The aim of this research is to provide information about the existence of mangrove in Karawang Regency. The method is by using Normalized Different Vegetation Index (NDVI) calculations on Landsat 8 2018 satellite imagery of Karawang to get the data that reveal the information. We have discovered that the existing of mangroves in Karawang Regency in 2018 is 305,14 Ha. Border coast that is vegetated is only $33.75 \mathrm{~km}$ of $77 \mathrm{~km}$ long coastline of Karawang. Only less than $5 \%$ of the total mangrove protected area in Karawang Regency is detected as mangrove from the total 9.055 Ha of the area.
\end{abstract}

Keywords: Coastal Vegetation, NDVI, Database, Coastal Management

\section{INTRODUCTION}

The importance of coastal ecosystems, such as mangroves, has been taken more attention lately. Not only it is beneficial to humans, mangroves also have been functioned as keepers of the world biodiversity. Coastal ecosystem, including mangroves, recently has been recognized as an essential role in controlling climate change and global warming. The damage of coastal ecosystem can cause the release of the more significant amount of carbon to the air more than the in-land ecosystem (Alongi, 2012) (Pendleton et al., 2012).
This fact has proven that mangrove, along with other coastal ecosystems, stores carbon more than terrestrial ecosystems. This sequestered carbon hold by coastal ecosystem nowadays known as Blue Carbon (Herr et al., 2012).

The northern part of Karawang is a coastal area with mostly mud-sand substrates. This substrate tends to be unstable, so that naturally, this kind of sediment is supported by coastal vegetation that forms coastal ecosystems, such as mangroves. The unstability of Karawang coast line is indicated by the extent of abrasion and accretion that occurs. The cause of the Karawang coast

Korespondensi Penulis:

${ }^{*}$ E-mail: ade.komarudin@karawangkab.go.id

DOI: http://dx.doi.org/10.15578/plgc.v2i1.8932 
unstability is suspected to be the significant conversion of mangrove forest into ponds which happened in the priod 1987-1990 (Sachoemar, 1994).

The government and related institutions need to make afforts to restored the stability of Karawang coastal sediment. To do so, information is needed as a basis for policies to be implemented. This reseach is conducted to provide basic information that is needed about the existing condition of mangrove in Karawang Regency. This research never been done in Karawang before. The resulting data will be needed not only as a database for government policies on coastal area management but also could be used for further research.

Our research objectives is to find mangroves in Karawang Regency; 2) What is the conditions of Karawang Regency's coast border (sempadan) vegetation and greenbelt length in 2018; and 3) What is the condition of mangrove in mangrove protected areas in Karawang Regency in 2018.

\section{MATERIAL AND METHODS \\ Description of the study sites}

The reseach location as shown in Figure 1. is 9 (nine) districts bordering the sea to represent Karawang Regency Coastal area. The district are Pakisjaya, Batujaya, Tirtajaya, Cibuaya, Pedes, Cilebar, Tempuran, Cilamaya Kulon and Cilamaya Wetan.

out 1) What is the conditions of

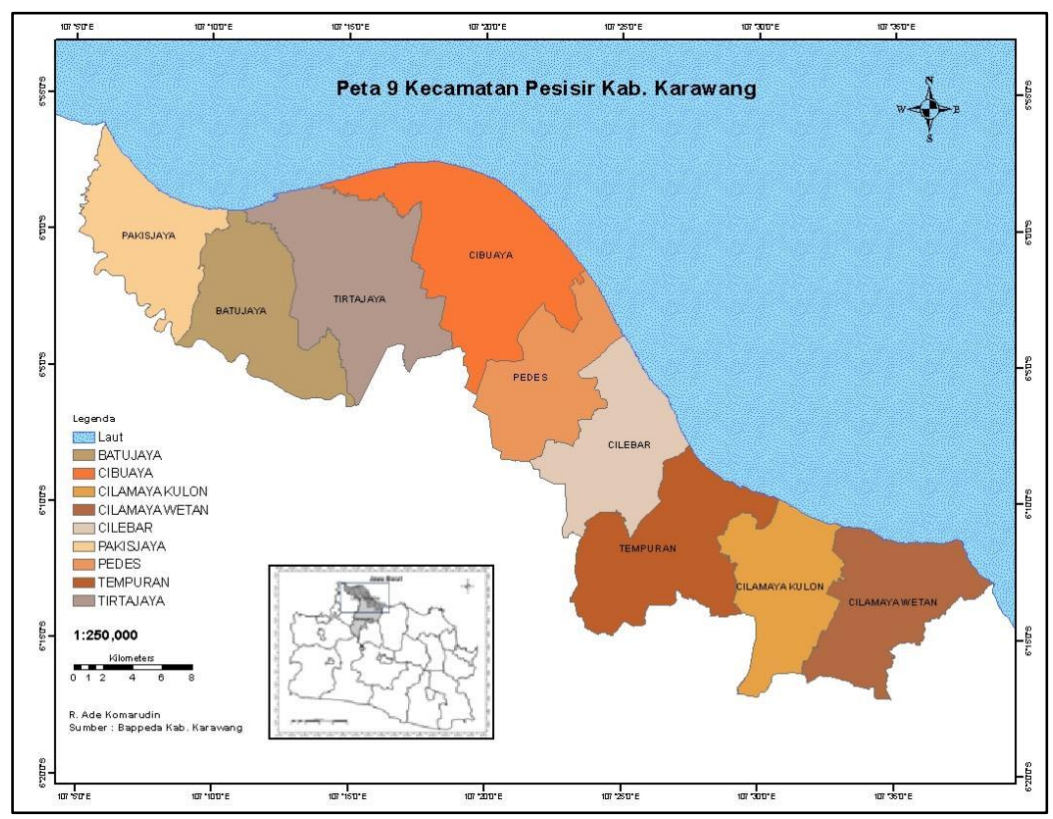

Figure 1. Karawang Coastal Districts

Data collecting method

As shown in the Figure 2, our research process is started by downloading one sheet Landsat 8 satellite imagery of Karawang from ESRI Earth
Explorer sites with the imagery date is 12 September 2018. This imagery was then processed with QGIS application and used as basic spatial data to identify the presence of mangrove. 


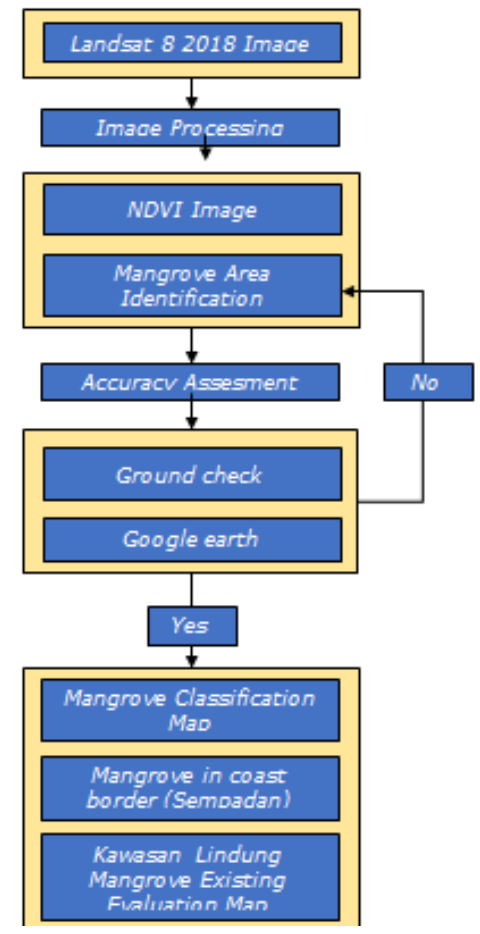

Figure 2. Research Design

The shape and canopies of mangrove trees and their specific location are very unique so that it is possible to detect them using satellite imagery. Satellite such as Landsat 8 could easily capture the precise image of mangrove. Ground check with coordinate samples and Google Earth data are used to strengthen the accuracy. The number of sample is determined by the mangrove area polygons produced in the satellites image interpretation process.

\section{Analysis Data}

Mangrove damage is then identified using Normalized Different Vegetation
Index (NDVI) calculations which are commonly used to find out the green index based on the following formula:

$$
\begin{gathered}
\text { NDVI }=\frac{\text { NIR- }}{\text { NIR }+}(\text { Nir }=\text { Band } 6, \text { Red }= \\
\text { Band 5) (Rouse, } \text { et al. } 1973)
\end{gathered}
$$

This index is classified based on the greenness level which is assessed with a scale of -1 to 1 where the pixel value increasingly positive near 1 indicates the level of greenness which indicates the density and thickness of the vegetation. The range index of damage to mangrove vegetation used in this study is as follows:

Table 1. NDVI Range of Mangrove Condition

\begin{tabular}{lll}
\hline Mangrove Conditions & Nilai NDVI & Covering Conditions \\
\hline No Mangrove & $<-0.3$ & No Covering \\
Damaged & $-0.3-0.15$ & Very Low Covering \\
Moderate & $0.15-0.25$ & Low Covering \\
Good & $0.25-0.35$ & Good Covering \\
Very good & $0.36-0.61$ & Very good Covering \\
\hline
\end{tabular}

Wahyunto, et al. (2003) 
The processed data is made as a digital map product. The produced maps are Map of Area and percentage of mangrove damage, map of border vegetation or increasingly positive near 1

\section{RESULTS AND DISCUSSION RESULTS}

Karawang Regency Mangrove Conditions

This study found that the area of mangroves in Karawang Regency in 2018 was $305,14 \mathrm{Ha}$. This findings is the result of satellites image interpretation process indicates the level of greenness which indicate areas. All maps show conditions in 2018 and all spawn spatial data for our research goal.

that has been been checked by 62 ground check samples. Based on NDVI analysis $15 \%$ or around $48.35 \mathrm{Ha}$ of the area is in damaged condition, $28.80 \%$ are moderate, and $34.43 \%$ or around 105.12 $\mathrm{Ha}$ of the mangroves are in good conditions as shown in Table 2 and Figure 3.

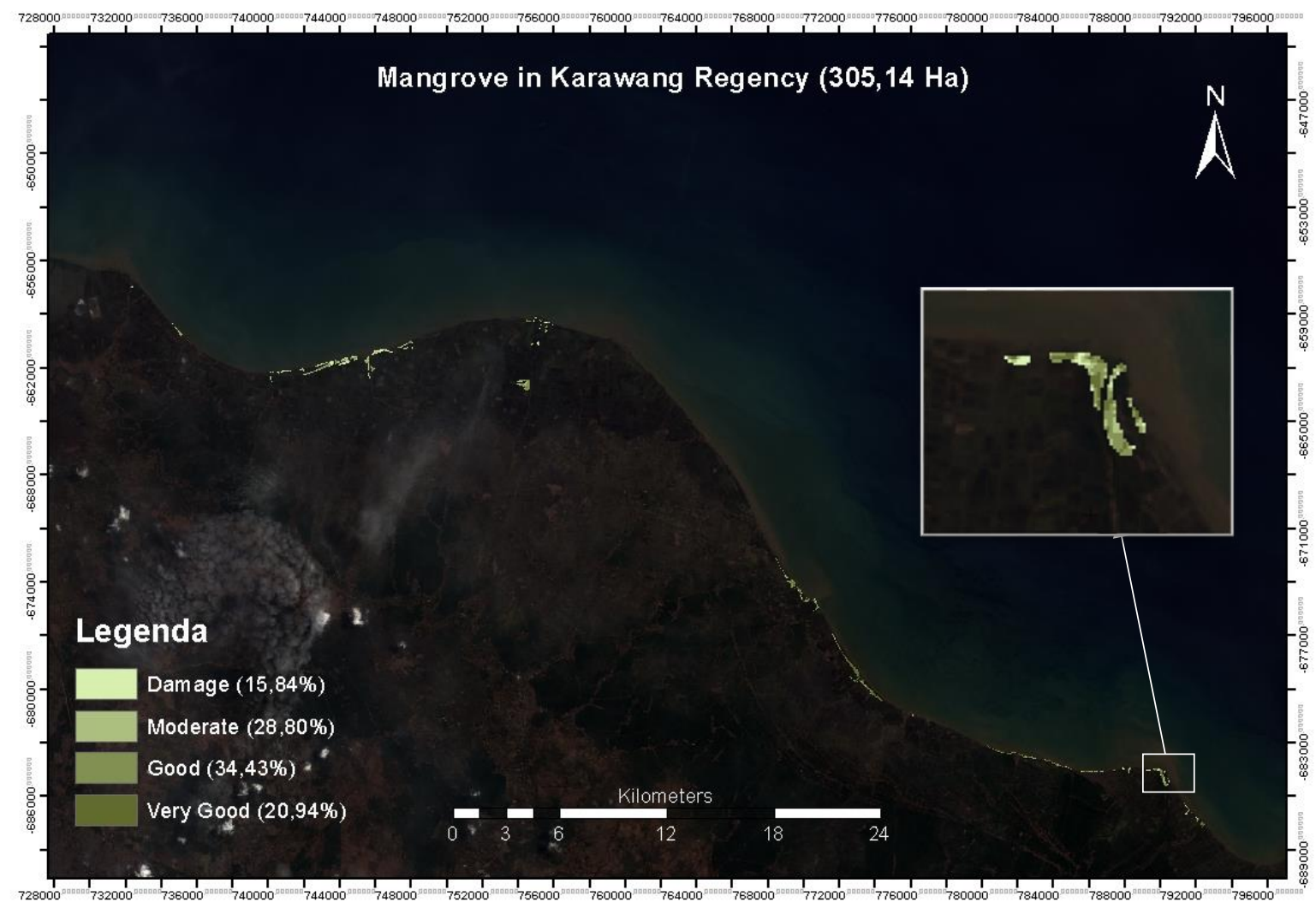

Figure 3. Mangrove existance in Karawang Regency 
Table 2. The cover and damage conditions of Mangrove in Karawang Regency

\begin{tabular}{clccccc}
\hline \multirow{2}{*}{ No. } & \multirow{2}{*}{ Coastal District } & \multirow{2}{*}{ Area $(\mathrm{Ha})$} & \multicolumn{4}{c}{ Conditions } \\
\hline Karawang (\%) & $\mathbf{1 0 0 , 0 0}$ & $\mathbf{1 5 , 8 4}$ & $\mathbf{2 8 , 8 0}$ & $\mathbf{3 4 , 4 3}$ & $\mathbf{2 0 , 9 4}$ \\
Karawang (Ha) & $\mathbf{3 0 5 , 1 4}$ & $\mathbf{4 8 , 3 5}$ & $\mathbf{8 8 , 0 1}$ & $\mathbf{1 0 5 , 1 2}$ & $\mathbf{6 3 , 6 7}$ \\
1. & Pakisjaya & 13,65 & 4,55 & 8,56 & 0,54 & 0,00 \\
2. & Batujaya & 4,91 & 1,13 & 3,40 & 0,38 & 0,00 \\
3. & Tirtajaya & 78,61 & 23,44 & 33,87 & 21,30 & 0,00 \\
4. & Cibuaya & 53,24 & 8,72 & 17,44 & 26,26 & 0,82 \\
5. & Pedes & - & - & - & - & - \\
6. & Cilebar & 84,68 & 4,13 & 9,43 & 30,26 & 40,86 \\
7. & Tempuran & 0,79 & - & 0,79 & - & 0,00 \\
8. & Cilamaya Kulon & 9,26 & - & 0,09 & 3,20 & 5,97 \\
9. & Cilamaya Wetan & 60,00 & 6,37 & 14,42 & 23,19 & 16,02 \\
\hline
\end{tabular}

Conditions of Karawang Regency's Vegetation Border (sempadan) and Greenbelt length in 2018

The width of the coast border "sempadan" in this research is considered as a constant of 100 meter from the highest tide point towards the land. The widht of coast border is determined based on the Indonesian coastal management law number 27 of year 2007 and the length is determined by the result of Karawang coast line digitations based on the satellite image. From those data, we have the area of Karawang coast border, which is $767 \mathrm{Ha}$. The NDVI value is calculated in the area and found that no vegetation is seen in $75.2 \%$ of the border.

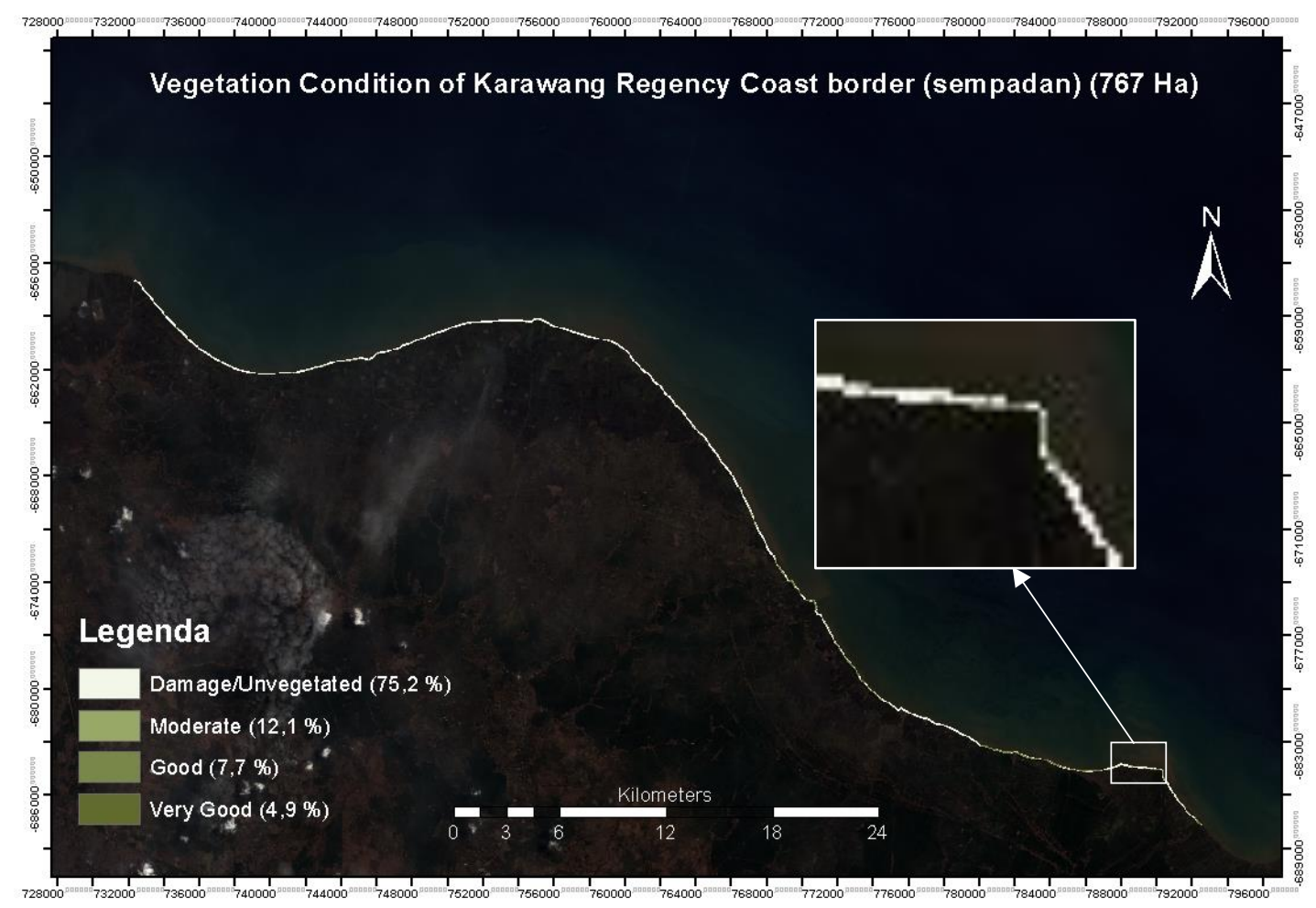

Figure 4. Vegetation condition of Karawang coast border 
The length of the green belt is calculated by measuring coastline that still covered by mangrove vegetation with NDVI range between moderate to very good condition. It has been found that the coastal length, which is still covered by mangrove vegetation is $33.75 \mathrm{~km}$ long. This data shows that more than $50 \%$ of Karawang Coastal areas are open without being protected by mangroves.

Mangrove conditions in mangrove protected areas in Karawang Regency in 2018

Mangrove protected areas based on the Spatial Plan Pattern of the Karawang Regency spatial map shown in Figure 5 are approximately 9 thousand hectares. This protected areas is specified in Karawang Regency regional regulation number 2 of 2013. With this significant extent, the area is expected to be an oxygen supplier for the regions "lungs" and also an environmental stabilizer in Karawang Regency. However, it is dissapointing that the presence of vegetation in the mangrove protected area is not as full as expected.

Our research shows that mangrove vegetation in the Karawang regency mangrove protected area that categorized moderate to very good on the NDVI range in 2018 is only $5.59 \%$. This area is managed by Perhutani which is a stateowned company that manages forest. Apparently much of this area land use has changed into other use by the local inhabitant without the company concern. The Government should concern with this result because this mangrove protected area needs to be restored to be able to fully function as a proper protected area. The vegetation condition that reveals by the research data of this mangrove protected area is underwhelming because it turns out that all this time the mangrove in this area is not protected at all.

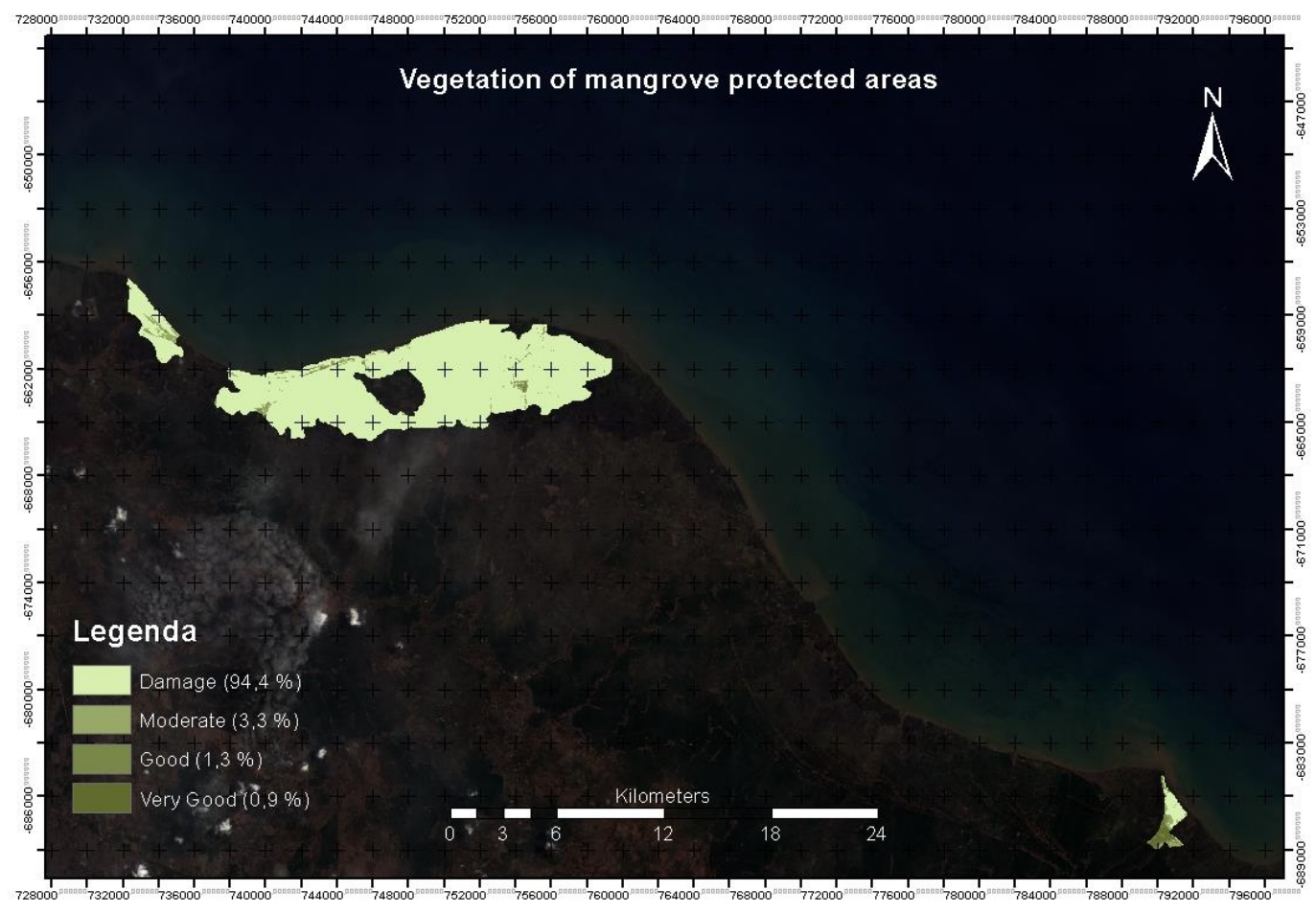

Figure 5. The vegetation of mangrove protected areas 


\section{DISCUSSION}

The absence of mangrove vegetations in the coast line of Karawang Regency is suspected as one of the causes on sediment instability in Karawang coastal area although further research is needed to add evidence of the allegation. Our result of Karawang mangrove condition is concerning. But other research located in the north java region since 2016 is reveal different information. The research located in Teluk Pangpang Banyuwangi (Kawamuna, et al., 2017) is shown the same mangrove condition with Karawang while the one conduct in Probolinggo (Maulidiyah et al., 2019) shows the mangrove condition there is better.

We have difficulties to find reference that conduct similar method to find vegetation border condition and greenbelt length to compare with our result. But in Sibolga, Zaitunah et al. (2018) conduct research on Greenbelt vegetation condition in 100, 200 and 500 meters width and found very low vegetation its quite similar with our research that most of the coast border (sempadan) vegetation is degraded and arid. The study about mangrove protected areas has been conduct by Ardiansyah (2019) in KPHL Gunung Balak shows better result than mangroves protected areas condition in Karawang.

\section{CONCLUSION}

The researchers conclude that the existing of mangroves in Karawang Regency in 2018 is $305,14 \mathrm{Ha}$. The NDVI value is calculated in the area and found that no vegetation is seen in $75.2 \%$ of the border. Although further research is needed, this condition may be one of the causes of sediment instability in the Karawang coastal area. The greenbelt also in the poor condition where more than $50 \%$ of Karawang Coastal areas are open without being protected by vegetation, especially mangroves. The condition of vegetation in the mangrove protected areas in Karawang Regency is mostly damage or even unvegetated where the vegetation detected by NDVI calculations with moderate to good conditions is only less than $5 \%$ of the total area which is $9.055 \mathrm{Ha}$.

\section{REFERENCE}

Alongi, D. M. (2012). Carbon sequestration in mangrove forests. Carbon Management, 3(3), 313322.

Ardiansyah, F. (2019). Penilaian Status Kesehatan Hutan Mangrove Menggunakan Teknik Forest Health Monitoring (FHM). Skripsi. Program Sarjana Universitas Lampung (UNILA). Lampung.

Maulidiyah, R., Cahyono, B. E., \& Nugroho, A. T. (2019). Analisis Kesehatan Mangrove di Probolinggo menggunakan Data Sentinel-2A. Natural B, 5 (2): 4148.

Herr, D., Pidgeon, E., \& Laffoley, D. (eds.) (2012). Blue Carbon Policy Framework 2.0: Based on the discussion of International Blue Carbon Policy Working Group. Gland, Switzerland: IUCN and Arlington, USA: CI. vi+39pp.

Kawamuna, A., Suprayogi, A., \& Wijaya, A. P. (2017). Analisis Kesehatan Hutan Mangrove Berdasarkan Metode Klasifikasi Ndvi Pada Citra Sentinel-2 (Studi Kasus: Teluk Pangpang Kabupaten Banyuwangi). Jurnal Geodesi Undip, 6(1), 277-284.

Pendleton, L., Donato, D. C., Murray, B. C., Crooks, S., Jenkins, W. A., Sifleet, S., ... , \& Baldera, A. (2012). Estimating Global "Blue Carbon" Emissions from Conversion and Degradation of Vegetated Coastal Ecosystems. PLoS ONE, 7(9): e43542. 
Sachoemar, S. I. (1994). Pemantauan Kondisi Ekosistem pantai dengan analisis citra Landsat dan data lapangan studi kasus wilayah pesisir Karawang. Tesis. Program Pascasarjana. Institut Pertanian Bogor.

Wahyunto S, Ritung, \& Widagdo. (2003). Laporan Akhir Teknologi Penginderaan Jauh untuk Efisiensi Inventarisasi dan Monitoring
Sumberdaya Lahan. Balai Penelitian Tanah. Puslitbang Tanah dan Agroklimat. Badan Litbang Pertanian.

Zaitunah, A., Samsuri, \& Slamet, B. (2018). Analysis of Greenbelt in Sibolga for Tsunami Mitigation. In IOP Conference Series: Earth and Environmental Science, 166(1): 012028). 